\title{
直流課電がいし連の部分フラッシオーバに関する研究
}

\author{
正員松 周 良輔 (日本ガイシ) \\ 正員伊藤進 (日本ガイシ) \\ 正員坂 西 健 治 (日本ガイシ)
}

\section{Investigation of Single Unit Flashover in HVDC Insulator Strings}

Ryosuke Matsuoka, Member, Susumu Ito, Member and Kenji Sakanishi, Member (NGK Insulators, Ltd.)

In the case of DC insulator strings, a special phenomenon, so called single unit flashover, has been recognized to occur under some special contaminated and wetted conditions not only in laboratories but also in actual lines.

Higher magnitudes of audible noise (AN), radio interference (RI), and television interference (TVI) from this single unit flashover may give a serious environmental impact to the neighbourhood of the transmission line. Some investigations have ever been made on this problem simulating such phenomenon under normal operating voltage conditions.

Here we explain the investigation results of single unit flashovers under cold-wet-switch-on conditions. Such a condition occurs when a de-energized transmission line is re-energized under a wet condition.

Higher occurrence probability of single unit flashovers was obtained under cold-wet-switch-on conditions compared with the case of normal operating voltage conditions.

Some candidates for countermeasures to suppress the single unit flashover have also been evaluated.

\section{キーワード：直流送電，部分フラッシオーバ，污損がいし，可聴雑音}

\section{1.まえがき}

直流送電線のがいし装置においては，污損湿潤条件 によっては，がいし連中の1〜2 個のがいしが大きな 放電音を伴う青白い連続アークによって橋絡される， 部分フラッシオーバを発生する場合のあることが知ら れている(1) (3)。部分フラッシオーバ発生時の騒音レ ベルは，活損湿潤がいしから通常発生する部分放電に 比べ非常に高く伝搬範囲も広いので，場合によっては 線路沿線の住民に対する障害が問題となる恐れもあ る。

部分フラッシオーバ現象は 1971 年に(財)電力中央
研究所塩原の $500 \mathrm{kV}$ 直流送電実験線に扔いて世界で 初めて観測され，人工污損がいしを含め，自然湿潤条 件下で種々部分フラッシオーバについて基礎調查が行 われた(1)。その後部分フラッシオーバ現象を系統的に 評洒するため, 長年にわたり実験室での再現に努力が はらわれてきた。その結果, 通常の人工污損試験の場 合より薄い霧の条件が，がいし連に沿った湿潤の不詓 等を生じやすくこの現象を再現できることがわかり， 乾燥時の直流フラッシオーバ電圧の高い大形がいしが 部分フラッシオーバの発生率を低く抑えるのに有効て あることが確認された ${ }^{(3)}$ 。

これまでは,がいし連が連続して課電されている条 
件での部分フラッシオーバの研究に限られていた。し かし，課電率の低い系統では，無課電時にがいしが湿 潤した後課電される場合もあり，今回このような条件 における部分フラッシオーバの発生確率や可聴雑音 (AN) 特性を調査した。また, 部分フラッシオーバ防 止対策についても調査した。

\section{2. 部分フラッシオーバ現象}

部分フラッシオーバは，がいし連中の一部のがいし の分担電圧が極端に大きくなり，がいし単体のフラッ シオーバ電圧より大きくなって発生すると考えられて いる。その発生プロセスを以下に示す。

（1）湿潤あるいは污損の不均等が原因で特定のが いしの表面抵抗が他のがいしの抵抗に比べ高くなる。

（2）抵抗の高いがいしの電圧分担が高くなり，そ のがいしの漏れ電流による発熱(ジュール熱)も大きく なる。

（3）このがいしは他のがいしに比べ乾燥効果が大 きく湿潤しにくくなるので，表面抵抗がますます大き くなり，分担電圧も高くなる。

(4) 分担電圧ががいし单体のフラッシオーバ電圧 を上回ると部分フラッシオーバが発生する。

交流課電がいし連では部分フラッシオーバ現象の発 生は確認されていない。交流の場合には，がいし表面 抵抗にアンバランスが生じても，がいしの自己容量, がいしと大地または線路との漂遊容量により電圧分担 が直流の場合ほど不均等にならないためである。

\section{3. 供試がいし}

供試がいしとして笠径 $320 \mathrm{~mm}$ の 16.5 トン直流が

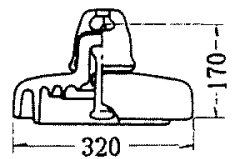
(3200C)
16.5ト直流がいし

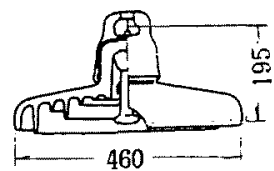

33トン直流がいし

(460DC)
図 1 供試がいし

Fig. 1. Test Specimen.

表 1 供試がいし連

Table 1. Specimen insulator strings.

\begin{tabular}{|c|c|c|c|}
\hline 適用電压 & がいし品名 & 運結個数 & 連結長 $(\mathrm{m})$ \\
\hline \multirow{2}{*}{ $\pm 250 \mathrm{kV}$} & $320 \mathrm{~mm} 16.5$ トン直流がいし & 34 & 5.78 \\
\hline & $460 \mathrm{~mm} 33$ トン直流がいし & 29 & 5.66 \\
\hline \multirow{2}{*}{ $\pm 500 \mathrm{kV}$} & 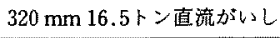 & 46 & 7.82 \\
\hline & $460 \mathrm{~mm} 33$ トン直硫がいし & 33 & 6.44 \\
\hline
\end{tabular}

いし（320 DC）と笠径 $460 \mathrm{~mm}$ の 33 トン直流がいし (460 DC) を選んだ。 $250 \mathrm{kV}$ 用がいし連については, $320 \mathrm{DC}$ の場合には設計塩分付着密度 $0.25 \mathrm{mg} / \mathrm{cm}^{2}$ 相 当の連結個数とし，460 DCの場合には $320 \mathrm{DC}$ とが いし連の長さがほほ同じとなる個数とした。 $500 \mathrm{kV}$ 用がいし連については, 設計塩分付着密度 $0.06 \mathrm{mg} /$ $\mathrm{cm}^{2}$ に相当する連結個数とした。供試がいし連はすべ て 1 連眯垂吊とした。供試がいしの形状を図 1 に，が いし連の寸法，諸元を表 1 に示す。

\section{4. 試験方法}

〈4・1〉 試料配置 供試がいし連および AN 測定 用マイクロホンの配置を図 2 に示す。

〈4・2〉 部分フラッシオーバ試験 部分フラッシ オーバの発生確認を以下の方法で調査した。

（i ）線路運転中に霧が発生し，がいしが湿潤する 場合の模擬（電圧先行法）污損乾燥させたがいし 連を霧室内につり下げ，一定の電圧を印加後, 湿度 $90 \sim 100 \%$ ，霧濃度 $0 \sim 0.4 \mathrm{~g} / \mathrm{m}^{3}$ の霧中で部分フラッ シオーバ発生の有無を30〜60 分間観察した。

（ii）無課電下でがいしが湿潤した後線路が課電さ れる場合の模擬（湿潤先行法）污損乾燥させたが
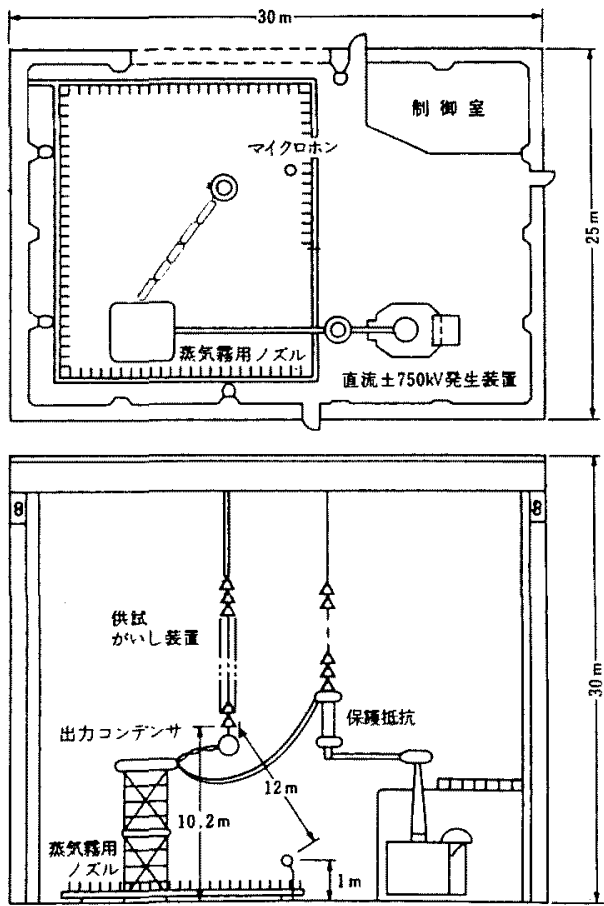

図 2 試料配置

Fig. 2. Test Arrangement. 
いしを霧室内につり下げた後, 第を発生させ, 霧室内 の湿度が 90〜95\%に達した時点で霧をいったん停止 し,がいし連に電圧を印加した。その後, 適宜霧を発 生させ $30 \sim 60$ 分間部分フラッシオーバ発生の有無を 観察した。

以上 $(i)$ ，（ii）の試験手順を図 3 に示す。

\section{〈4・3〉 部分フラッシオーバ防止対策の調查}

部分フラッシオーバの発生を防止するには，（i 分 担電圧の不均等が生じないようにする方法, 例えば全 面導電釉がいしを採用すること，(ii)例え電圧分担の 不均等が生じても，単体のがいしがフラッシオーバし ないようがいし単体のフラッシオーバ電圧を高くする 方法などが考えられる。今回, がいし連中にシリコー ングリースを塗布したがいしを何個か挿入することに よって, 湿潤時, がいし連全体に印加されている電压 をこれらシリコーングリース塗布がいしで分割して負 担させることにより, 部分フラッシオーバの発生が防 止できるのではないかと考光，その防止効果を確認し た。また， $320 \mathrm{DC}$ がいしに比べ笠径が大きくフラッ シオーバ電圧の高い $460 \mathrm{DC}$ を $320 \mathrm{DC}$ からなるがい し連に㨂入した場合の防止効果についても調査した。

$\langle 4 \cdot 4\rangle$ AN 特 性 An(Audible Noise)につい ては, IEC Pub. 651-1971に規定の騒音計を用い, 1 インチのコンデンサマイクロホンを供試がいし連から $12 \mathrm{~m}$ の位置に置き， $A$ 特性の音圧レベル実効值を測 定した。試験を実施した試験室は音響学的には残響室

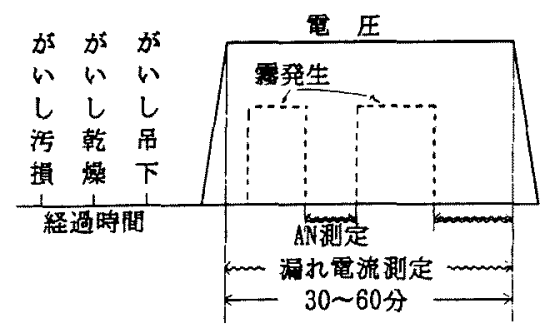

(i) 電圧先行

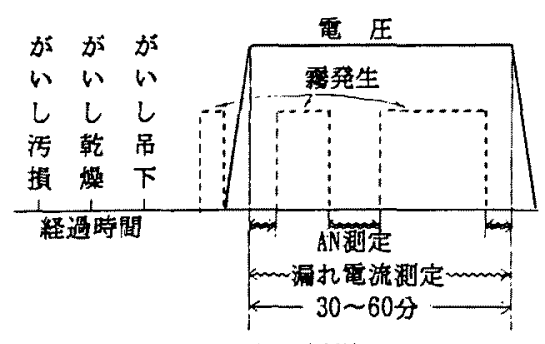

(ii) 湿汪告先行法

図 3 試験手順

Fig. 3. Test Procedures.
に近いので, 試験室の壁面での反射および吸収に対す る補正については, 正弦波発信器と無指向性スピーカ を用いて残響時間を測定し，次式(4)により音響パワー レベル $P W L(\mathrm{~A})$ を算出した。

$P W L(\mathrm{~A})=(S P L)_{r}+C_{1}-C_{2}$

ここで, $(S P L)_{r}:$ 室内での測定音压レベル

$[\mathrm{dB}(\mathrm{A})], C_{1}$ : 発生源加ら $12 \mathrm{~m}$ 地点の音圧

レベルと $P W L$ の比, $C_{2}$ : 部屋の音響特性

により定まる補正値

測定の結果, $C_{1}=33 \mathrm{~dB}(\mathrm{~A}), C_{2}=10 \mathrm{~dB}(\mathrm{~A})$ であっ た。また，部分フラッシオーバによる $\mathrm{AN}$ の自由勂 間における伝搬については，測定点が音源から十分離 れれば，発生源は点音源と見なせるので，音源から十 分離れた地点の音圧レベル $(S P L)_{f}$ は, 次式により求 められる。

$(S P L)_{f}=P W L(\mathrm{~A})-20 \log L-11$

$L:$ 発生源加ら測定点への直線距離 $(\mathrm{m})$

\section{5. 試験 結 果}

〈5・1〉 部分フラッシオーバ試験結果 部分フラ ッシオーバ試験結果を表 2 に示す。なお, 部分フラッ シオーバの発生状況の一例を図 4 に示す。

（1）湿潤条件の影響電圧先行よりも湿潤先行 のほうが部分フラッシオーバが発生しやすい。なお湿 潤先行の場合でも，がいし表面の湿潤が過度な場合に は, 局部アークは発生するが, 部分フラッシオーバは 発生しにくくなる。

（2）印加電圧極性の影響 部分フラッシオーバ の発生に及ぼす極性の影響は見られない。

（3）印加電圧值の影響 印加電圧が高くなると 部分フラッシオーバ発生確率も高くなる傾向を示す

表 2 部分フラッシオーバ試験結果

Table 2. Test results of single unit flashover.

\begin{tabular}{|c|c|c|c|c|}
\hline 䉓压印加法 & $\begin{array}{c}\text { 印加電压 } \\
(\mathrm{kV})\end{array}$ & $\begin{array}{c}\text { 供試がいし } \\
\text { 装 置 }\end{array}$ & $\begin{array}{c}\text { 塩分付着密度 } \\
\left(\mathrm{mg} / \mathrm{cm}^{2}\right)\end{array}$ & $\begin{array}{l}\text { 部分 FO } \\
\text { 発生率 }\end{array}$ \\
\hline \multirow{3}{*}{ 電庄先行 } & -500 & $320 \mathrm{DC} \times 46$ & 0.054 & $0 / 2$ \\
\hline & \multirow{2}{*}{-250} & $320 \mathrm{DC} \times 34$ & 0.227 & $0 / 4$ \\
\hline & & $460 \mathrm{DC} \times 29$ & 0.213 & $0 / 3$ \\
\hline \multirow{7}{*}{ 湿潤先行 } & \multirow{2}{*}{--500} & $320 \mathrm{DC} \times 46$ & 0.057 & $5 / 8$ \\
\hline & & $460 \mathrm{DC} \times 33$ & 0.055 & $1 / 4$ \\
\hline & +500 & $320 \mathrm{DC} \times 46$ & 0.053 & $4 / 7$ \\
\hline & \multirow{4}{*}{-250} & \multirow{2}{*}{$320 \mathrm{DC} \times 34$} & 0.229 & $0 / 4$ \\
\hline & & & 0.058 & $3 / 5$ \\
\hline & & \multirow{2}{*}{$460 \mathrm{DC} \times 29$} & 0.224 & $0 / 3$ \\
\hline & & & 0.055 & $0 / 5$ \\
\hline
\end{tabular}

注) 部分 FO 発生率は, 部分 FO 発生回数/詮驗回数を亦す。 


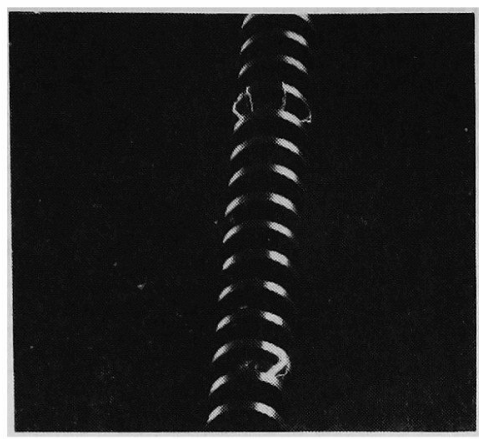

図 4 部分フラッシオーバ発生状況 Fig. 4. An example of single unit flashover.

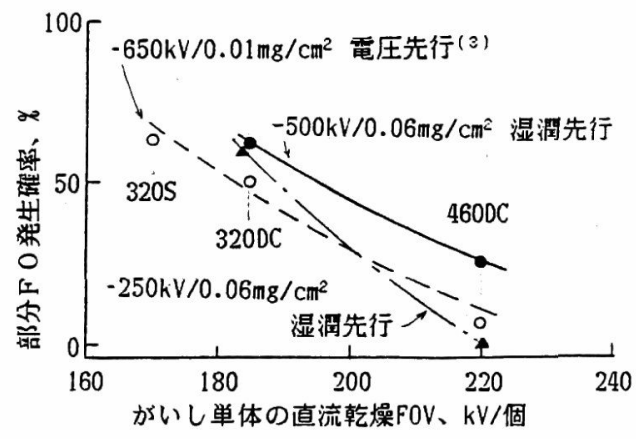

図 5 がいし単体の直流乾燥フラッシオーバ 電圧 $(\mathrm{FOV})$ と部分フラッシオーバ 発生確率の関係

Fig. 5. Relation between DC dry FOV and occurrence probability of single unit flashover.

が，320 DC の場合には顕著な差は見られなかった。 なお，人工污損がいしの自然湿潤条件下での試験では がいしの平均分担電圧が同じでも，がいし連全体の印 加電圧が高いほど部分フラッシオーバ発生確率は高く なるとの結果が得られている(2)。

（4）がいし形状の影響笠径が大きくがいし単 体のフラッシオーバ電圧の高い $460 \mathrm{DC}$ のほうが 320 $\mathrm{DC}$ よりも部分フラッシオーバ発生確率は低くなる傾 向が見られる。

がいし単体の直流乾燥フラッシオーバ電圧と部分フ ラッシオーバ発生確率の関係を図 5 に示す。図には過 去に当社で実施した電圧印加後霧を発生させた場合の 結果も記した ${ }^{(3)}$ 。同図より，単体のフラッシオーバ電 圧の高いがいしほど，部分フラッシオーバ発生確率は 低くなることが明らかである。ただし，これは部分フ ラッシオーバ発生時のがいしのフラッシオーバ電圧が
がいし単体の乾燥フラッシオーバ電圧と同等であるこ とを示すものではない。

（5）塩分付着密度の影響 塩分付着密度が高い 場合には，部分フラッシオーバは発生しなかった。な お, 人工污損がいしの自然湿潤条件下での電圧先行法 による試験結果によれば，塩分付着密度があるレベル を超えると急激に発生しやすくなると報告されてい $ろ^{(2)}$ 。このように自然湿潤条件下と人工湿潤条件下 で, 塩分付着密度に対する部分フラッシオーバの発生 確率の傾向が大きく異なる原因としては，以下のよう なことが考えられる。部分フラッシオーバ発生時の漏 れ電流は通常数 $\mathrm{mA}$ 以下であり，これを超えると部 分フラッシオーバは発生せず，一般の污損試験時と同 様局部アークが発生しやすくなる。このため実験室で の部分フラッシオーバ試験の場合には, 人工霧の注入 量を污損耐電圧試験の場合の $1 / 10$ 以下としている。 このように霧の注入量を少なくしても, 塩分付着密度 が高い場合には，塩の潮解性のためがいし表面污損層 は湿潤しやすく, 部分フラッシオーバを発生する湿潤 条件に比べ湿润過多となりやすい。これに対し自然湿 潤の場合には，一般にがいし表面の湿潤の進行が遅く またその度合も低いため，湿潤のアンバランスは比較 的生じにくい。このため, 自然湿潤条件下では漏れ電 流によりがいし表面の湿潤乾燥のアンバランスが生じ やすい重污損の場合のほうが, 部分フラッシオーバの 発生確率が高くなると推測される。

\section{〈5・2〉 部分フラッシオーバ防止対策調查結果}

調査試験結果を表 3 に示す。

（1）湿潤度が低い条件では, シリコーングリース 塗布がいしを 5 個以上挿入することにより部分フラッ シオーバは防止できたが, 湿潤度が高い条件では 5 個 挿入してもシリコーングリース塗布がいしで部分フラ ッシオーバが発生した。これは表 3 に示すように, シ リコーングリース塗布がいし単体の耐電圧が湿潤条件 により大きく変化するためと考えられる。

（2）表 3 の結果から, 捜入したシリコーングリー ス塗布がいしの耐電圧とシリコーングリース塗布がい しの插入個数の積が印加電圧以上の場合には部分フラ ッシオーバが防止でき，それ以下の場合には防止でき ないようである。

（3） 320 DC がいし連に 460 DC がいしを 5 個插 入したが部分フラッシオーバは防止できなかった。部 分フラッシオーバは $320 \mathrm{DC}$ がいしで発生した。

〈5・3〉 AN 特 性 調查結果を表 4 に示す。

（1）通常がいし連の場合, 部分フラッシオーバ発 生時の音響パワーレベルは $96 \sim 111 \mathrm{~dB}(\mathrm{~A})$ であり, 
表 3 部分フラッシオーバ防止対策試験結果

Table 3 . Investigation results of countermeasures against single unit flashover.

\begin{tabular}{|c|c|c|c|c|}
\hline 印加電在 & \multicolumn{4}{|c|}{$-500 \mathrm{kV}$} \\
\hline 塩分付皓密度 & \multicolumn{4}{|c|}{$0.06 \mathrm{mg} / \mathrm{cm}^{2}$} \\
\hline 供碔がいし連 & \multicolumn{3}{|c|}{$320 \mathrm{DC} \times 46$} & $320 \mathrm{DC} \times 41+460 \mathrm{DC} \times 5$ \\
\hline 対 策 & $\begin{array}{c}\text { ジリコーンダリース堡有 } \\
\text { がいし } 5 \text { 個挿入 }\end{array}$ & 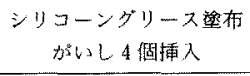 & $\begin{array}{c}\text { シリコーングリース㴏布 } \\
\text { がいし } 5 \text { 個捙入 }\end{array}$ & 460 DC を 5 個掩入 \\
\hline 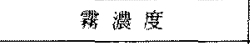 & $0 \sim 0.2 \mathrm{~g} / \mathrm{m}^{3}$ & $0 \sim 0.2 \mathrm{~g} / \mathrm{m}^{3}$ & $3 \sim 5 \mathrm{~g} / \mathrm{m}^{3}$ & $0 \sim 0.2 \mathrm{~g} / \mathrm{m}^{3}$ \\
\hline 部分 FO D発生率 & $0 / 5$ & $2 / 3$ & $2 / 3$ & $2 / 3$ \\
\hline 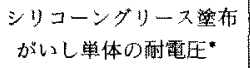 & \multicolumn{2}{|c|}{$120 \mathrm{kV} /$ 䀦 } & $60 \mathrm{kV} /$ 個 & - \\
\hline
\end{tabular}

部分 $\mathrm{FO}$ 発生率は, 部分 $\mathrm{FO}$ 発生回数/詰䮖回数寺示す。

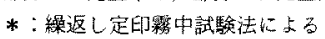

表 4 部分フラッシオーバ発生時の AN 特性

Table 4. AN level of single unit flashover.

\begin{tabular}{|c|c|c|c|}
\hline $\begin{array}{c}\text { 印加電纴 } \\
(\mathrm{kV})\end{array}$ & 供試艻いしし装置 & $\begin{array}{c}\text { 塩分付着密度 } \\
\left(\mathrm{mg} / \mathrm{cm}^{2}\right)\end{array}$ & $\begin{array}{l}\text { 部分 } \mathrm{FO} \text { 発生時 } O \\
\text { 最大 } \mathrm{AN} \\
\quad[P W L(\mathrm{~A})] \mathrm{dB}\end{array}$ \\
\hline \multirow{2}{*}{-500} & $320 \mathrm{DC} \times 46$ & 0.057 & 105 \\
\hline & $460 \mathrm{DC} \times 33$ & 0.055 & 99 \\
\hline+500 & $320 \mathrm{DC} \times 46$ & 0.053 & 111 \\
\hline-250 & $320 \mathrm{DC} \times 46$ & 0.058 & 96 \\
\hline \multirow{3}{*}{-500} & 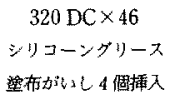 & 0.052 & 102 \\
\hline & 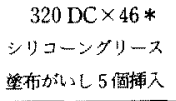 & 0.054 & 99 \\
\hline & $\begin{array}{c}320 \mathrm{DC} \times 41 \\
+ \\
460 \mathrm{DC} \times 5\end{array}$ & 0.053 & 93 \\
\hline
\end{tabular}

*:蓩水量 $3 \sim 5 \mathrm{~g} / \mathrm{m}^{3}$, 他の試䮖は $0 \sim 0.4 \mathrm{~g} / \mathrm{m}^{3}$

局部アーク発生時は最大 $95 \mathrm{~dB}(\mathrm{~A})$ であった。部分フ ラッシオーバ発生時の AN の波形の一例を図 6 に示 के。

送電線から $50 \mathrm{~m}$ 地点の騒音レベルを計算すると部 分フラッシオーバ発生時は $66 \mathrm{~dB}(\mathrm{~A})$ ，局部アーク発 生時は, $50 \mathrm{~dB}(\mathrm{~A})$ となる。な扔, 交流 $500 \mathrm{kV}$ 送電 線における降雨時の電線コロナによるANは，線路 加 $50 \mathrm{~m}$ 地点において約 $50 \mathrm{~dB}(\mathrm{~A}) て ゙ あ り り^{(5)}$, 部分 フラッシオーバ発生時の騒音レベル法非常に高いこと がわかる。

（2）がいしの種類による騒音レベルの差は明確で はなかった。

（3）シリコーングリース慗布がいしを聥入した場 合の部分フラッシオーバ発生時の音響パワーレベル は, 99 102 dB(A)であり, 通常がいし連のレベル

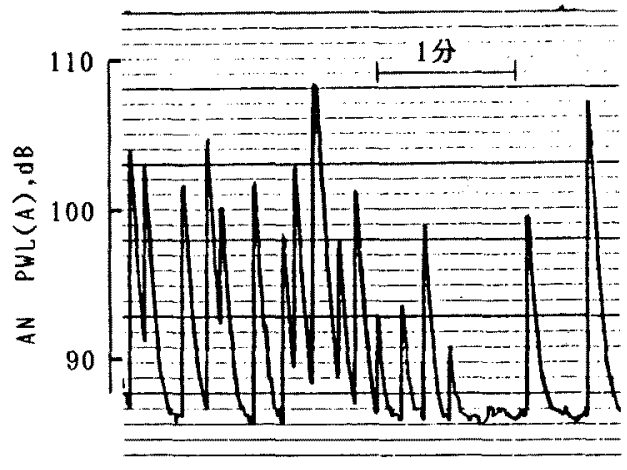

図 6 部分フラッシオーバ発生時の $\mathrm{AN}$ 波形例

Fig. 6. An example of oscillogram of AN caused by single unit flashover.

105〜111 dB より低かった。これは，がいし連全体に 印加されている電圧の一部が，他のシリコーングリー ス塗布がいしで分担されるため, 部分フラッシオーバ 発生がいしの分担電㽵が通常がいし連の場合の值より 低いためと考えられる。

\section{6.あとがき}

今回の研究により，

（1）部分フラッシオーバ発生確率は湿溜先行のほ うが電圧先行の場合より高くなること。

（2）湿潤先行であっても部分フラッシオ一バ発生 時の騷音レベルなどの特性は電圧先行の場合と ほぼ同じであること。

（3）湿潤先行の条件下でも，がいし単体の乾燥条 件下で直流フラッシオーバ電圧の高いがいし ほど, 部分フラッシオーパの発生確率は小さく なること。 
などが確認できた。

なお, 部分フラッシオーバは, いったん発生すると 数時間以上継続する場合があり，またその騒音レベル も高く広範な地域へ伝搬する。海外の $\pm 500 \mathrm{kV}$ 級直 流送電線では, 特に深刻な環境問題となっていない が, 国土の狭い我が国では, 部分フラッシオーバの周 囲に及ほす影響が心配される。今後, 部分フラッシオ 一バの発生を抜本的に防止する対策の確立に努めてい きたい。

(平成 3 年 5 月 28 日受付, 同 3 年 9 月 10 日再受付)

\section{文献}

（1）福島・須永：「直流送電線の雑音と騷音（第 3 報）, がいし連 の部分閃絡による雑音と騒音の実験的検討」, 電研技術第 1 研報, 73075 (昭 49)

（2）福島：「送電線のコロナ䂈音」, 電研総合報告：TOI, (昭 61 年)

（3）内藤・長谷川・加藤・小川：「直流がいし装置の污攅湿潤時 の RI, TVI およびAN特性】, NGKレビュー, No.48, (昭63)

(4) 守田：騒音と騒音防止 (昭 49) オーム社

（5）UHV 交流送電実証委員会：UHV 交流送電に関する実証研 究, Z85801 (昭60)

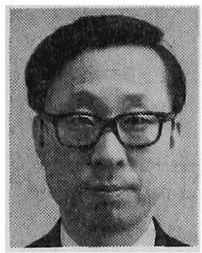

松 岡 良 輔 (正員)

昭和 16 年 4 月 15 日生。 41 年 3 月名 古屋大学大学院工学研究科修士課程修 了。同年 4 月日本碍子(株) 入社。主とし て,がいしの污損特性に関する研究に従 事。IEEE Senior Member, 日本沙漠学会会員。

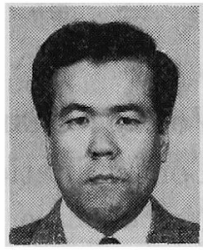

\section{伊藤進 (正員)}

昭和 23 年 9 月 21 日生。 44 年 3 月鈴 鹿工業高等専門学校電気工学科卒業。同 年日本碍子(株) 入社。現在, 同社超高圧 研究所に勤務。主として, がいしの高電 圧試験研究, 污損特性に関する研究に従事。

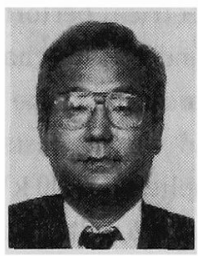

坂 西 健 治 (正員)

昭和 18 年 9 月 15 日生。 37 年 3 月県 立岐阜工業高校電気科卒業。同年 4 月日 本碍子(株)入社。主として, がいしの污 損特性に関する研究に従事。 